Instructions for authors, subscriptions and further details:

\title{
Gender Equity, Student Loans and Returns on Investment in American Higher Education
}

Amany Saleh ${ }^{1}$

QianQian $\mathrm{Yu}^{1}$

H. Steve Leslie ${ }^{1}$

John Seydel ${ }^{1}$

1) Arkansas State University. United States

Date of publication: June $25^{\text {th }}, 2017$

Edition period: June 2017-October 2017

To cite this article: Saleh, A., Yu, Q., Leslie, H. S., Seydel, J. (2017). Gender Equity, Student Loans and Returns on Investment in American Higher Education. International Journal of Sociology of Education, 6(2), 216-243. doi:

10.17583/rise.2017.2633

To link this article: http://dx.doi.org/10.17583/rise.2017.2633

PLEASE SCROLL DOWN FOR ARTICLE

The terms and conditions of use are related to the Open Journal System and to Creative Commons Attribution License (CC-BY) 


\section{Gender Equity, Student Loans and Returns on Investment in American Higher Education}

Amany Saleh

Arkansas State University

H. Steve Leslie

Arkansas State University
QianQian Yu

Arkansas State University

John Seydel

Arkansas State University

(Received: 16 March 2017; Accepted: 16 May 2017; Published: 25 June 2017)

\section{Abstract}

This study examines practices that impact females' earnings and, in particular, their ability to repay student loans. Salary inequities experienced by female college graduates along with student loans are addressed. The authors offer a quantitative model for highlighting the inequity in the American workforce considering female's lower salaries and higher student loans by examining the payback period associated with the investment in college education. Results indicate that, while the payback period for investments on college loans is increasing for both males and females, this trend is significantly worse for females.

Keywords: gender equity, higher education, student loans, return on investment in higher education (ROI), payback period 


\section{Equidad de Género, Préstamos Estudiantiles y Rendimientos de la Inversión en la Educación Americana}

Amany Saleh

Arkansas State University

H. Steve Leslie

Arkansas State University
QianQian Yu

Arkansas State University

John Seydel

Arkansas State University

(Recibido: 16 Marzo 2017; Aceptado: 16 Mayo 2017; Publicado: 25 Junio 2017)

\section{Resumen}

Este estudio examina las prácticas que impacto las ganancias de las mujeres y, en particular, su capacidad para pagar los préstamos estudiantiles. Las desigualdades salariales experimentadas por los graduados universitarios de las mujeres junto con los préstamos estudiantiles se abordan. Los autores ofrecen un modelo cuantitativo para destacar la inequidad en la fuerza de trabajo estadounidense considerando los salarios más bajos de las mujeres y los préstamos estudiantiles más altos examinando el período de recuperación asociado con la inversión en la educación universitaria. Los resultados indican que, mientras que el período de recuperación para las inversiones en préstamos universitarios está aumentando tanto para hombres como para mujeres, esta tendencia es significativamente peor para las mujeres.

Palabras clave: equidad de género, educación superior, préstamos estudiantiles, retorno de la inversión en la educación superior (ROI), período de amortización

2017 Hipatia Press

ISSN: 2014-3575

DOI: $10.17583 /$ rise. 2017.2633

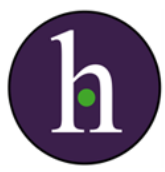




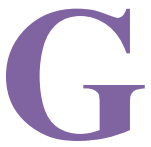

ender inequality in post-secondary education in the U.S. has been decreasing gradually since the 1980s. Nowadays, there are more females than males enrolled in post-secondary education and gaining more higher education degrees and such trends are expected to continue (Doherty, Willoughby, \& Wilde, 2016; Ewert, 2012; Kena et al., 2016; Snyder, de Brey, \& Dillow, 2016; Snyder, Tekleselassie, Mallery, \& Choi, 2013).

Scholars have suggested that female students have been exceeding male students in college graduation rates for many reasons including the; (1) decrease of gender discrimination, restructuring of occupations, reform of social norms and family structures, and the increase of female students enrolled in college (DiPrete \& Buchman, 2006; Goldin et al., 2006; as cited in Ewert, 2012). Although female students have been increasing in college enrollment, attainment, and graduation rates compared to males, there remain questions regarding gender equality and gender equity. Given the facts that women still earn significantly less than men, that most American students rely on loans to attend college, that tuition in higher education has increased, and that women have to take more student loans than men, can we still claim that we are closing the gender gap? Do females have more burdens to pay off their student loans after graduation? Do these factors contribute to holding women back or keeping them in secondary places to men when it comes to their financial status?

In this paper, the authors review literature regarding female students in higher education and changing women roles in society. Next, the authors explore literature concerning women's student loans and pay inequality. Then they employ the social stratification theory to examine the return on investment (ROI) for higher education and develop a model to describe the payback associated with that ROI. Using the data on the tangible money associated with student loans and subsequent salaries, that model is then applied to develop an equation that statistically describes the inequality in the payback period across genders, in particular, that results from gender disparities in student loans and post-graduation pay. 


\section{Objective of the Study}

In today's well-advanced countries, women are viewed as having the same opportunities as men. However, upon further examination of current practices and values regarding gender, many disparities and inequities become visible. This study explores the inequality of women's earnings in terms of their impact on their abilities to repay student loans, taking on shared or sole responsibility of providing for their families, and taking active and leading roles in the economy. Is the ROI in education for women equitable with that of men?

\section{Theoretical Framework}

Bowles (2013) defined social stratification as, “. . . the systematically unequal distribution of power, wealth, and status" within society (p. 33). Literature suggests that the way men and women are treated in any society is indicative of the power dynamics, wealth and status of men versus women within a particular society (Bowles, 2013; Kerbo, 2000).

Women in our current times represent the majority of college graduates and participate in the work force (Ginder, Kelly-Reid, \& Mann 2016), but still struggle for equity. Women are more likely than before to be the breadwinners of their families or even have bigger salaries than their husbands (Parker, 2016). Still women earn lower salaries than their male peers for the same jobs (Corbett, Hill, \& AAUW, 2012), take on more college loans, and take longer to repay these loans (AAUW, 2016a). This makes their return on investment in education lower than that of males. The graph below illustrates this relationship. As women earn more college education, take on more breadwinners roles, take more student loans, they still earn less than their male peers and take longer to repay their student loans, which put them at a disadvantage to men. The graph lends support to the gender stratification theory that posits the exiting societal power dynamics and distribution of wealth keep women from reaching equity regarding their $\mathrm{ROI}$ in education. 


\section{Literature Review}

\section{Women in Higher Education}

Research indicates that college enrollment of women outnumbers that of men in the U.S. (2016). Ginder, Kelly-Reid, and Mann (2016) reported that female students enrolled in degree-granting institutions in the 2014-2015 school year accounted for $58.1 \%$, compared to $41.9 \%$. male students Degrees awarded to female students made up 58\% while male students $42 \%$. All indicators give the impression that we are living in a world that is closing the gender gap; however, inequality persists. The gender gap is closing at a slow pace even though the roles of women in the society are changing at a fast pace.

\section{Changing Roles of Women in Society}

Married women are more likely than before to be the primary breadwinners of their families. "Among married couples with children, the total family income is highest when the mother, not the father, is the primary provider" (Parker, 2016, p. 4). Over 22\% of families have the mother as the sole earner of the family. In over $40 \%$ of American households with children, women are the primary breadwinners with almost two thirds of them being single moms (Finningan, 2015).

According to Parker (2016), 23\% of couples have a wife with a higher educational level attainment, and $38 \%$ of them earn more than their husbands. These females generally have a higher student loan debt as well. Still women are more likely to take maternity leave, or time off to take care of their children or ageing parents (Parker, 2016). Having higher debt as well as taking time off cumulatively negatively impacts women's ability to ascend the career ladder compared to male colleagues.

\section{Women Student Loans}

Tuition and fees in higher education have significantly increased in the last two decades (Ehrenberg, 2007; Willie, 2012). Lucca, Nadauld, and Shen 
(2016) reported that $\$ 1.3$ trillion of student debt has become "the largest form of non-mortgage liability for households." Renehan (2015) stated that attending college has changed from an intellectual pursuit to a financially burdensome risk for students and their families and that it is more than ever before necessary for students to have financial aid and parental support in order to attend college. Hill (2016) argued that 53\% of females, compared with $39 \%$ of males, pay more money to their student debt than they can reasonably afford.

According to an American Association of University Women (AAUW) report (2016a), women tend to take out more student loans than men and take longer to repay these loans. In the same report, women still earn an average of 79 cents for every dollar men make. This makes repaying student loans more burdensome for women than for men.

Corbett, Hill, and American Association of University Women (2012), in their report stated that,

as college costs rise and more students borrow more money to finance their education, a surprisingly large and growing percentage of students -especially women -are graduating with high levels of student loan debt burden. ... Student loan debt affects both men and women, but it is especially onerous for many women. ... Women are especially likely to have high student debt burden, largely because of the pay gap. (p. 26)

In the AAUW report, researchers examined a cohort of college graduates who were employed full time and found that men repaid $44 \%$ of their debts in four years compared to $33 \%$ for women for the same time period. Comparatively, African American and Hispanic women repaid less than $10 \%$ after four years. However, they pointed out these women were contributing more of their income to repay their debts compared to men despite the pay inequity.

\section{Pay Inequality}

In the past, women's roles were limited to homemaking and child rearing. This restricted their aspirations and accessibility of higher education and 
professional occupations. When women pursued work it was believed that they are seeking temporary jobs or trying to provide supplementary family income. Such beliefs led to the long-held practice of offering low salaries to women compared to men with the same level of education and for the same jobs.

Corbett et al (2012) stated that, "Nearly 50 years after the passage of the Equal Pay Act of 1963, women continue to earn less than men do in nearly every occupation" (p. 1), and progress in closing the gender gap in payment has been slow. Kitroeff and Rodkin (2015) found that women with MBAs were earning a median of $\$ 35,000$ less than men eight years after graduation and took a year longer to repay their student loans than men. Additionally, they found that student loans took $25 \%$ of women earnings compared to $14 \%$ of the men's earnings.

\section{Research Methodology}

The authors formulated a mathematical model especially taking into consideration student loans and pay inequality. The authors employ a grounded theory design which is defined as, "A systematic, qualitative procedure used to generate a theory that explains, at a broad conceptual level, a process, an action, or an interaction about a substantive topic" (Creswell, 2012, p. 423). In this paper, the authors rely on pure monetary investment to measure the ROI in education, without taking into consideration the intangible social returns for education, such as better health, longevity, and life satisfaction.

\section{Model Development}

Using a systematic approach of collecting data, the authors have developed a quantitative model that can be used to analyze the data regarding female education, student loans, and gender inequality. To develop that model, the authors reviewed the data on the enrollment and degrees awarded to women's higher education, gender gap in salaries, student loans of higher education in the United States, and loan repayment rates. Having developed the model, the authors:

1. Use model to evaluate the existing inequality in ROI, focusing 
in particular on females' ability to pay-off student loans, and

2. Develop recommendations for decreasing the gender gap in the ROI for higher education.

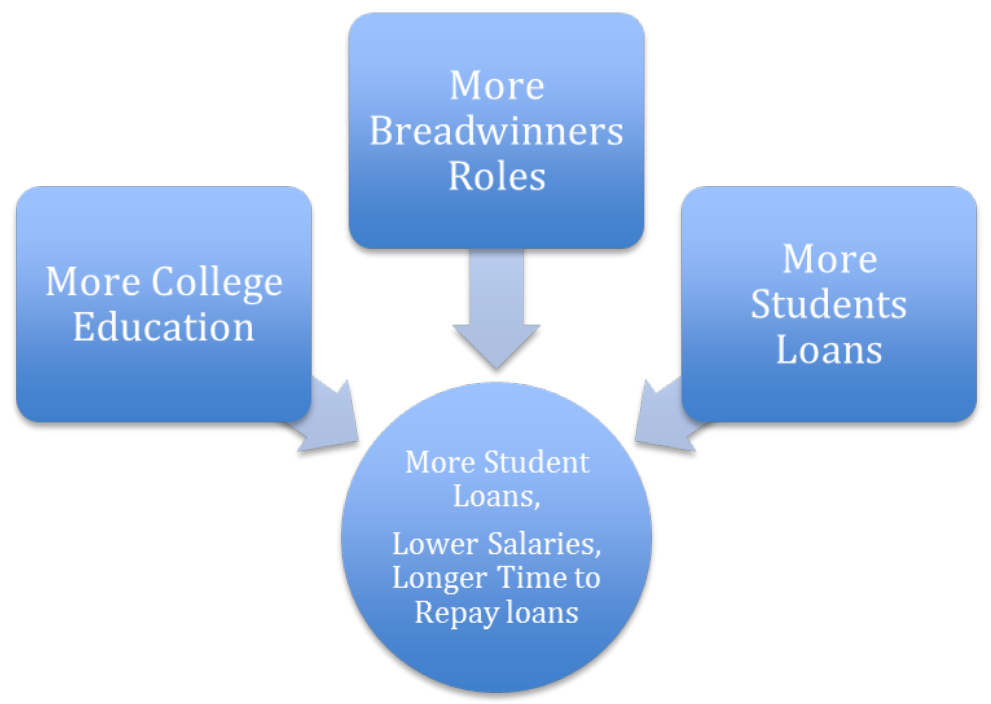

Figure 1. Model Graph of the Return on Investment in Education for Women

\section{Data Collection}

Data concerning male and female full-time full-year workers (ages 25 to 34) with bachelor's degrees or higher in the aspects of median annual salaries and student loans were collected and analyzed (see Figures 2 through 5, and Tables 1 through 3). A formula based on the data provided was developed to examine how the gender inequality in terms of ROI is in the US.

\section{Measuring Financial Performance}

Various financial measures are available for evaluating the efficiency of an investment, e.g., a college education, and arguably the most commonly discussed of these measures is the return on investment (ROI). While ROI is 
most often reported as a ratio of net benefits to net investments for a given investment option, alternatively the net return (NR) is sometimes reported instead. Net return is simply equal to the net benefits from an investment, which is that the total benefits minus the total costs of those investments. Related to the ROI and NR (and often used in place of those as measures of financial performance) are the payback period (PBP) and the internal rate of return (IRR). The PBP is the number of years required for the net benefits from an investment to cover the costs associated with that investment. A decrease in the PBP corresponds to an increase in the ROI (and NR). The IRR, which increases along with the ROI, is a more sophisticated measure and takes into account the time value of money, which neither the PBP nor the ROI (or NR) consider. However, for many high-level analyses (such as that conducted in this paper), the PBP or ROI measures will suffice for a general comparative analysis. Thus, providing a reasonable picture of the situations being addressed. In general, an improvement in the ROI (and NR) corresponds to improvements in the PBP and IRR (Gitman \& Zutter, 2015). The analysis as follows shows that over time females earn less than males although more females are graduating from institutions of higher education.

\section{Analysis and Results}

\section{Pay Inequality}

The NCES data show that the medial salary for men was $\$ 57,750$ (in constant 2014 dollars), whereas women earned \$46,250 (NCES 2016). This indicates a difference of $\$ 11,500$ or $24.86 \%$ lower salary for women when compared to men. Median male and female salaries over a 20-year time frame as illustrated in Figure 2 shows the trend of men earning consistently more than women. 


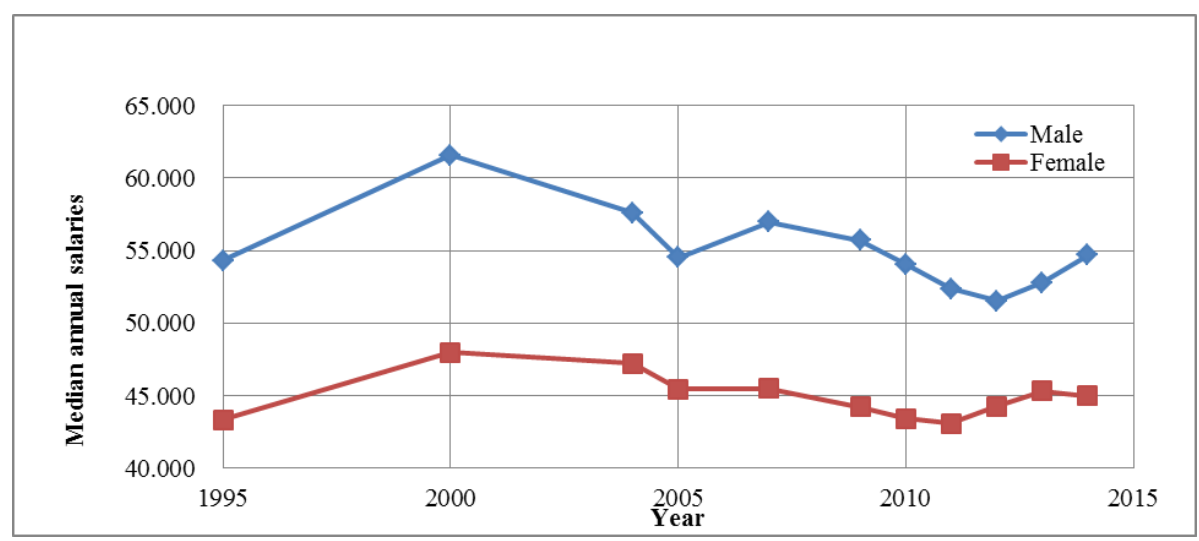

Figure 2. Median annual earnings for full-time full-year workers (ages 25 to 34) with bachelor's degrees or higher. Data source: U.S. Department of Commerce, Census Bureau, Current Population Survey (CPS), Annual Social and Economic Supplement, 1996 through 2015.

As shown in Figure 2, the actual gap in average salaries for women is consistently lower than men's salary. In 1995 there was a difference of $24 \%$. In 2000 this gap widened to $28.3 \%$. In 2005 there was a reduction to $19.9 \%$. This shrinking of the gap did not last because in 2010 the gap widened to $24.5 \%$. From 2010 to 2015 there was another narrowing of the salary gap. However, the trajectory shows that the salaries for females will remain constant whereas the salary for males is poised to increase. Thus, there is an overall negative trend for females in salary gap over the 20-year period represented by the data.

In addition, this negative trend line for females is further explained by a regression analysis illustrated in Figure 3 and summarized in Table 1. The analysis shown in Figure 3 examines the gap in median annual salaries of females when compared to males over a 20-year period from 1996 through 2015 in constant 2014 dollars. In fact, the $\mathrm{R}^{2}$ of .3676 shows a weak trend. That is, it indicates it is hard to predict the trend in gender disparities in terms of median annual earnings. Regardless of the weak trend, the "Pvalue" of 0.047980533 in Table 1 shows a statistical significance, meaning that this is a statistically significant trend. Although this is a statistically significant trend, it is almost hardly considered as a significant trend from a practical standpoint as the "P-value" is so close to 0.05 . In addition, the 
value of -190.72372 (the "X Variable 1" coefficient in Table 1) indicates an average annual decrease of $\$ 191$ in that gap. This means that the decreased gap per year in terms of salary amount is so small between females and males.

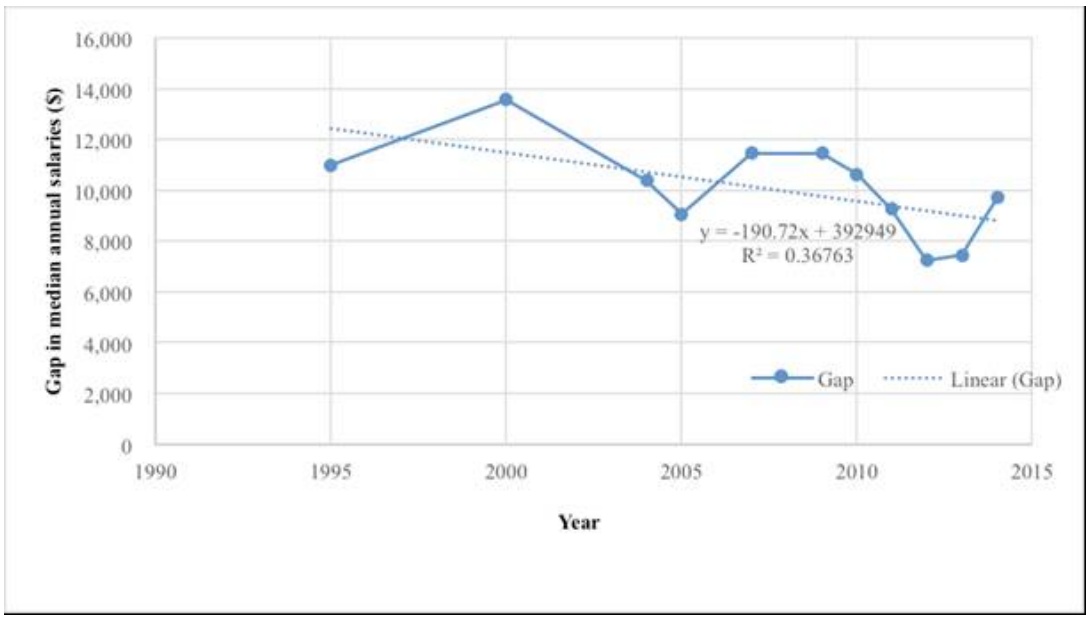

Figure 3. Gender gap of median annual earnings for full-time full-year workers (ages 25 to 34) with a bachelor's degree or higher from 1995 through 2014 (in constant 2014 dollars). Data source: U.S. Department of Commerce, Census Bureau, Current Population Survey (CPS), Annual Social and Economic Supplement, 1996 through 2015. 
Table 1

Regression analysis of gender gap in salaries with a bachelor's degree or higher Regression Statistics

\begin{tabular}{lc}
\hline Multiple R & 0.6063211 \\
R Square & 0.3676252 \\
Adjusted R Square & 0.2973614 \\
Standard Error & 1546.8992 \\
Observations & 11
\end{tabular}

ANOVA

$\begin{array}{lccccc} & d f & S S & M S & F & \text { Significance F } \\ \text { Regression } & 1 & 12519798.45 & 12519798.45 & 5.232067119 & 0.047980533 \\ \text { Residual } & 9 & 21536074.27 & 2392897.142 & & \\ \text { Total } & 10 & 34055872.73 & & & \end{array}$

Coefficients Standard Error $\quad t$ Stat P-value

$\begin{array}{lllll}\text { Intercept } & 392949.06 & 167369.4247 & 2.347794799 & 0.043461805\end{array}$

$\begin{array}{lllll}\text { X Variable } 1 & -190.72372 & 83.38118313 & -2.287371225 & 0.047980533\end{array}$

\section{Return on Investment}

Greenwood Hall, an education technology company, surveyed 2000 adults, 900 of whom were college graduates to gauge their perception of their ROI in education (Ruderman, 2016). Over 50\% of them perceived that recent 
college graduates are receiving less ROI compared to those who graduated 10-15 years earlier. It was argued that the primary reason for the lower ROI rate was the increased cost of student loans.

In 2008, the total NR for education in the United States for males was $\$ 567,331$, while it was $\$ 252,577$ for females (ROI in Tertiary Education Report, 2013). The total NR included the benefits for the individual and the society. It was calculated by adding the net private return, which included tuition, food, books, housing, and lost earning while enrolled in college. The net public return was calculated by adding tax revenue, reduced social liability such as public assistance then subtracting unpaid taxes during college and state/federal spending on education. The report acknowledged that several variables such as major and occupational choices, gender, equity, and social expectations influence the gender difference.

A major concern about student loans is the ability to repay them, and this has been an issue of importance to all college students, especially to female students. Although the data used in this study show that women incur slightly less loan debt than men on average, the salary gap leads to greater difficulty for women in repaying their loans.

To consider the gender gap in terms of ROI, it can be helpful first to note the trend in student loans, which essentially serves as a crude proxy for investment. Since 1999, the average annual loan amounts have increased for both male and female students, as indicated in Figure 4. 


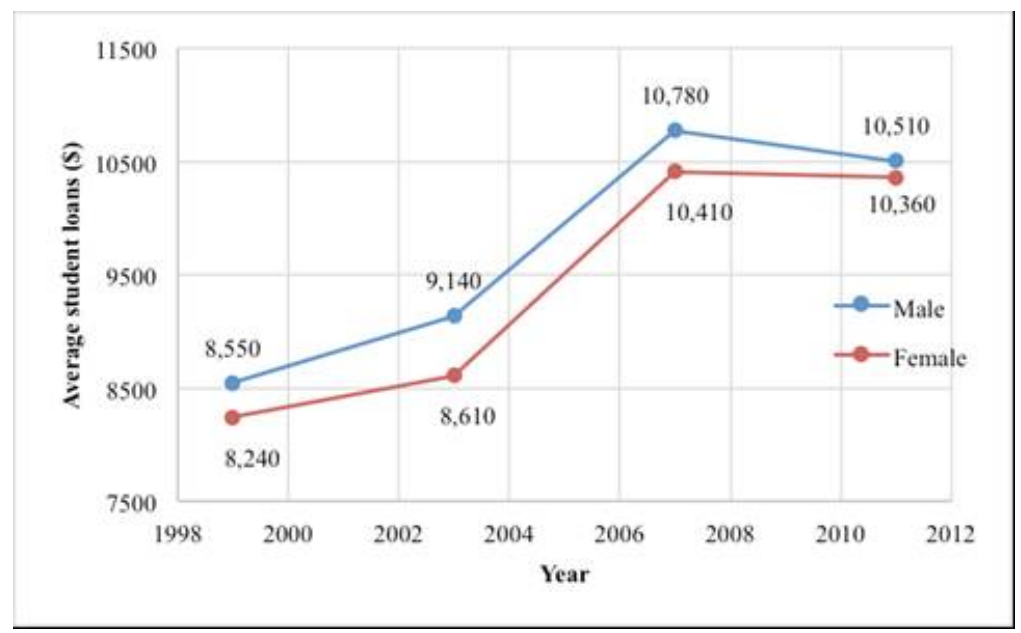

Figure 4. Average annual amount of student loans for full-time, full-year undergraduates by genders Selected years, 1999-2000 through 2011-12 (in constant 2014 dollars). Data source: U.S. Department of Education, National Center for Education Statistics, 1999-2000, 2003-04, 2007-08, and 2011-12 National Postsecondary Student Aid Study (NPSAS, 2000, 2004, 2008, \& 2012).

Assuming that loans represent the bulk (although not the sum total) of student investment in education and that this investment is paid out over four years one can consider the return on that investment as being realized by salaries in the years following graduation. For comparison purposes and assuming salary growth to be the same for males and females, one can look at a single year's salary somewhere around five years after graduation. Such a year might be considered representative of the annual return, once the graduate has started gaining traction in his or her career.

Given the above suppositions, along with the NCES data, a crude annual ROI measure for each of four selected graduation years between 1999 and 2011 can be calculated for male and female students. For example, the average male student loans for the 1999-2000 academic year were $\$ 8,550$. In addition, a reasonable assumption is that the average student takes out loans for six years prior to graduation. Therefore, the average total college investment for those males can be estimated as $6^{*} 8550=\$ 51,300$ per student. The return on that investment five years later (i.e., 2004) was an 
average salary of $\$ 57,600$, which yields a ratio of 1.12 , i.e., an annual ROI of $12 \%$. Per the same estimation process, the return ratio for women was 0.95 (i.e., an ROI of $-5 \%$ ) for the same time period. (Note that a negative ROI ordinarily implies a financial loss, and that the ROI values here represent the ratio of returns for a single year to the total loan amount invested in the average student's college education. Considering the entire life of the investment would certainly yield positive and relatively large ROI values for both males and females). However, the purpose here is simply to compare the ROI for males and females, and the single year ROI is sufficient for that. The gap in return ratios for that period was 0.17 . Figure 5 illustrates this gender-gap based upon the data for the four selected time periods available in the NCES data.

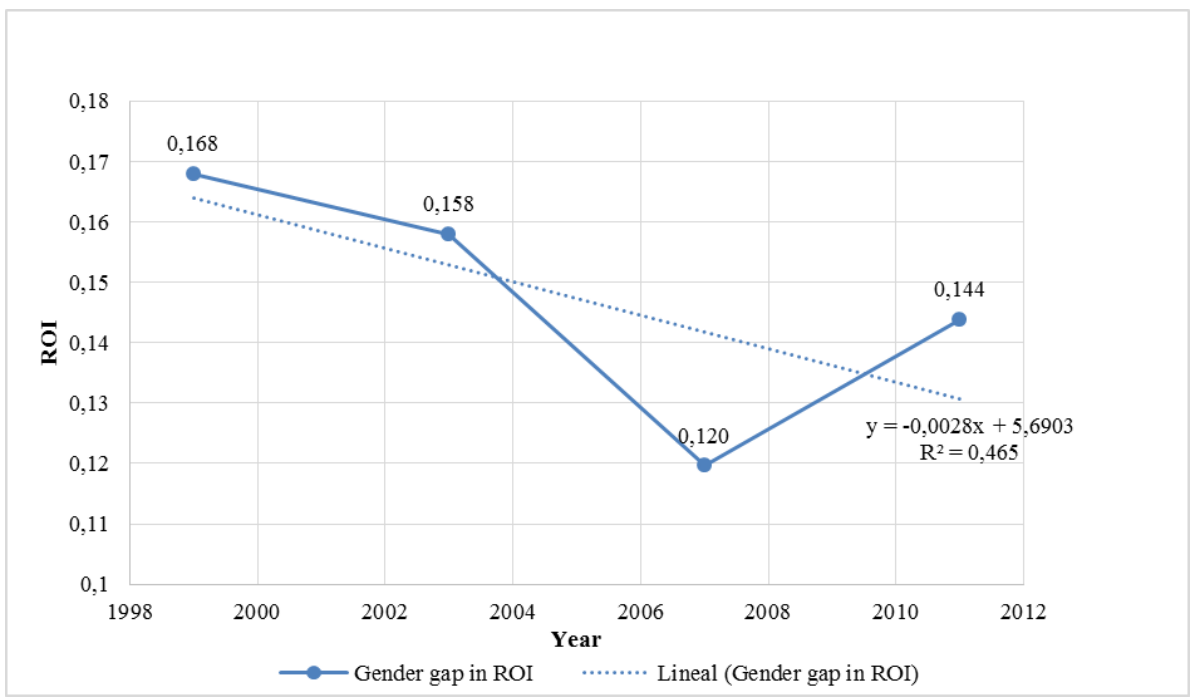

Figure 5. Gender gap in ROI for full-time full-year workers (ages 25 to 34) with a bachelor's degree, selected years, 1999-2000 through 2011-12 (in constant 2014 dollars). Data sources: U.S. Department of Commerce, Census Bureau, Current Population Survey (CPS), Annual Social and Economic Supplement, 1996 through 2015; U.S. Department of Education, National Center for Education Statistics, 19992000, 2003-04, 2007-08, and 2011-12 National Postsecondary Student Aid Study (NPSAS, 2000, 2004, 2008, \& 2012). 
As can be seen from figure 5, while this gender gap persists, there may be an apparent decreasing trend in the gap. However, that trend is not statistically significant $(p=0.318)$. Although this analysis includes only four data points, it nevertheless provides helpful insights into the persisting lack of equality of opportunity for women as compared to men. That is, based upon the data, it cannot be concluded that the gender gap in ROI is decreasing. In fact, the persistence of the gender gap in returns on investment in higher education can be clearly seen through an analysis of the payback period, i.e., how long it takes to recoup the loans required to finance a college education.

\section{Student Loan Payback Model}

The following model, focusing on the payback period (PBP), can be used to provide another perspective for exploring the ROI gap based upon the loan and salary data in the NCES reports. That is, it can be very helpful to consider how long it might take to repay loans taken out during college years. Let $t$ represent a student's college graduation year and let $y_{t}$ be the PBP, the number of years' worth of the median salary needed to pay back loans accumulated during the student's undergraduate years. Then, if the following represent variables corresponding to values available from the data,

$s_{t}=$ Median salary for year $t$

$l_{t}=$ Average loan amount for year $t$

and the following parameters (i.e., assumption values)

$T=$ Average number of years to complete bachelor's degree

$I=$ Inflation rate

apply, then the PBP for students graduating in year $t$ is

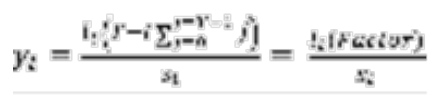

The numerator here represents the total loans taken out during $\mathrm{T}$ years of 
college, where the graduation year's loan amount, $l_{t}$, occurs $T$ times but is adjusted for inflation, $I$, each year prior to graduation. This assumes the following:

- Entry level salary is the median salary for year of graduation

- All of first year's salary (and part of the second year's salary) goes to paying off the student loans

- Average loan amount for graduation year is borrowed each of the preceding $T$ years, but discounted for inflation at an annual rate of $I$

Table 2 summarizes the results of the calculations for $y_{t}$, the average payback period, where $T$, the average number of years required to graduate, is 6 , and the annual inflation rate, $I$, is $5 \%$. For example, according to the available data, values for $s_{t}, l_{t}$, and $y_{t}$ are calculated for 2009 as follows. The inflation compounding factor is calculated as Factor $=6-0.05 *(0+1+2$ $+3+4+5)=5.25$, which means that the PBP for males graduating in 2009 would be $y_{t}=(10780 * 5.25) \div 55700=1.016$, while that for females would be $y_{t}=(10410 * 5.25) \div 44240=1.235$. From Table 2 , we can see that males' salaries consistently are more in comparison to females', while females take longer time to repay their student loans in comparison to males via PBP from the year of 2000 through the year of 2012. In addition, the student loans between females and males are close. 
Table 2

Student loan payback period (PBP) for female and male undergraduates

\begin{tabular}{lccc}
\hline Graduation Year & Criterion & Male & Female \\
\hline 2000 & Salary $\left(s_{2000}\right)$ & 61550 & 47970 \\
& Loan $\left(l_{2000}\right)$ & 8550 & 8240 \\
& PBP $\left(y_{2000}\right)$ & .0729 & 0.902 \\
& Salary $\left(s_{2004}\right)$ & 57600 & 47210 \\
& Loan $\left(l_{2004}\right)$ & 9140 & 8610 \\
& PBP $\left(y_{2004}\right)$ & 0.833 & 0.957 \\
& Salary $\left(s_{2009}\right)$ & 55700 & 44240 \\
& Loan $\left(l_{2009}\right)$ & 10780 & 10410 \\
& PBP $\left(y_{2009}\right)$ & 1.016 & 1.235 \\
& Salary $\left(s_{2012}\right)$ & 51530 & 44280 \\
& Loan $\left(l_{2012}\right)$ & 10510 & 10360 \\
& PBP $\left(y_{2012}\right)$ & 1.071 & 1.228 \\
\hline
\end{tabular}

Figure 6 provides a graphical illustration of the upward trend in PBP for both genders, as well as the gender effect on that trend. As can be seen in this figure, the $y_{t}$ values for women (i.e., those above the dotted trend line) are consistently above those for men. 


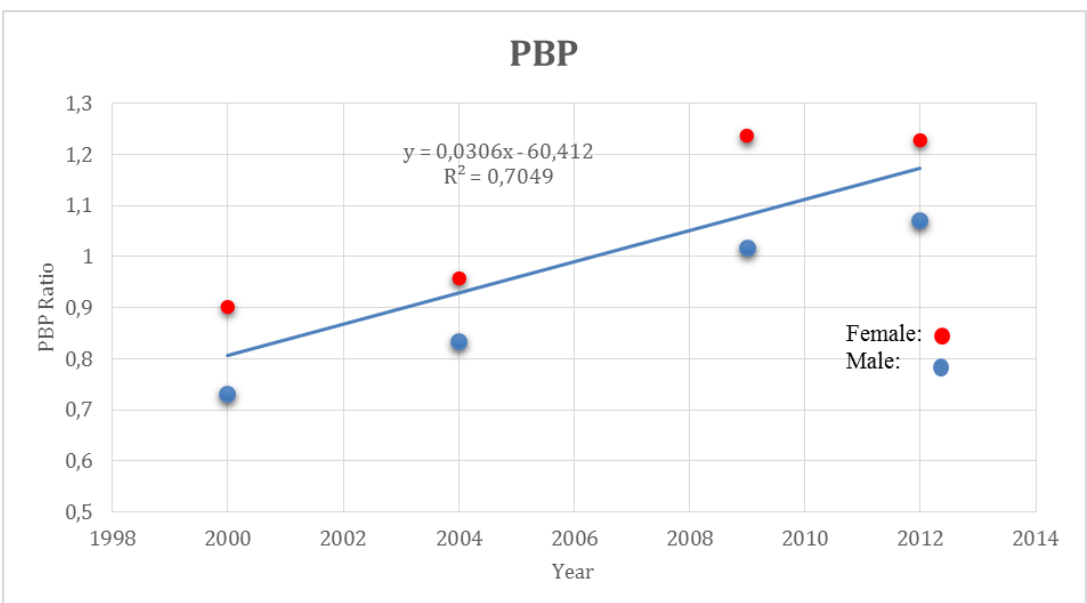

Figure 6. Payback period (PBP) for full-time full-year workers (ages 25 to 34) with a bachelor's degree, selected years, 1999-2000 through 2011-12 (in constant 2014 dollars) by gender. Data sources: U.S. Department of Commerce, Census Bureau, Current Population Survey (CPS), Annual Social and Economic Supplement, 1996 through 2015; U.S. Department of Education, National Center for Education Statistics, 1999-2000, 2003-04, 2007-08, and 2011-12 National Postsecondary Student Aid Study (NPSAS, 2000, 2004, 2008, \& 2012).

A regression analysis of the PBP considering the trend in terms of PBP, as moderated by the gender variable, is summarized in Table 3. Of no surprise, the trend effect, a positive value, is significant at the "P-value" < 0.00389549 level, which substantiates the various concerns often expressed in the literature. This simply indicates that, the PBP has been increasing for both genders. However, more notable is the value of the gender effect, as provided by the regression analysis. It shows this effect to be an average of 0.168 years' worth of salary (as indicated by the X Variable 2 coefficient) required to pay off their student loans. In other words, the average PBP for females is 0.168 years more than for males. 
RISE - International Journal of Sociology of Education, 6(2) 235

Table 3

Regression analysis of student loan payback period

Regression Statistics

R Square

0.956726233

Standard Error $\quad 0.044157646$

Observations $\quad 8$

ANOVA

$d f$

SS

$M S$

F

Significance F

Regression

2

0.215548403

0.107774202

55.27172106

0.000389549

Residual

5

0.009749488

0.001949898

Total

7

0.225297892

Standard

Coefficients

Error

t Stat

p-value

Intercept

$-60.49646613$

6.804690832

$-8.890406284$

0.00029961

X Variable 1

0.030608732

0.003391728

9.024523445

0.000279049

$\mathrm{X}$ Variable 2

0.168441072

0.031224171

5.39457308

0.002955221 


\section{Summary Remarks}

While the gender gaps in salaries, student loans, and financial returns on investment in higher education may be decreasing, as indicated by Figures 2 through 5, the gaps persist for the study years. In particular, a substantial gap in the overall affordability of college education, as reflected by the PBP is the result of the combined gender inequities in post-graduation salaries and higher dependence of females on student loans. It clearly takes longer for females on average to repay their college loans than it does for males, and this serves as a major impediment to the financial success and equal progress of females in modern society. The statistical model we offered in this study proves that despite the gains in women's education, access to the workforce and improved salaries, the gap in the return on investment (ROI) as reflected by the Pay Back Period (PBP) we offered lends support to the persistent gender inequality in our society.

Senator Elizabeth Warren at a recent conference, as reported by Izadi (2014) stated, "It is a one-two punch . . . women take on big debts to go to college, but they have less money to pay off these debts." Similarly, Catherine Hill wrote, "People still don't believe that gender is still an issue. a lot of people think this is something of the past, that women seem to be doing well in education" (AAUW, 2016b, para. 4). She contended that women pay more than men for college because they take longer to repay their loans considering their lower salaries and interest on the loans. Our model of analyzing supported this by calculating debt repayment based on gender inequality of salaries.

As college tuition continues to increase, student loans are expected to be $\$ 2.5$ trillion over the next ten years (Long, 2010). This will further increase the gap between males and females if we don't address the inequality of gender-based salaries. This study provides a clear evidence of the impact of gender pay inequality on females' ability to pay back their loans. This problem may contribute to women declining to pursue higher education.

This inequality can also prevent women from taking risks by changing jobs, taking leadership roles, or starting their own business. The research of Ayala, Lerner, and Schwartz (2010) indicates that, "Gender differences reinforce the explanation for women's entrepreneurial inferiority as resulting 
from social and economic exclusion and lack of equality. . . [coupled with] difficulties in gaining access to capital and lack of information and assistance" (p. 191). The authors further state that along with grappling with work-life balance, women have tended to be worse off as entrepreneurs compared to their male counterparts due to these inequities. These factors support the stratification of society by gender. The society expects or forces women to take "safe" jobs to provide for their families, while expects men to be aggressive and take more risks during their careers. In many instances stable jobs pay less and have little chances for career advancement, while more risky jobs pay more, have higher dividend, and offer more chances for advancement.

According to social stratification theory, when there is an unequal distribution of resources to any member or group within a society, it is very likely that the group will be defined, positioned and treated in an unfair manner (Bowles, 2013; Kerbo, 2000). This study illustrates how women are viewed and treated by the male-dominated culture and how these views contribute to the persistent gender inequality in salaries despite the changing role of women in the society.

With the passing of the Equal Pay Act of 1963 and the Lilly Ledbetter Fair Pay Act of 2009 there has been significant improvement in the area of gender equity in the United States. The model in Figure 7 provides a snapshot of the many gender equity issues women continue to face in the American society. The model illustrated in Figure 7, reflects the societal impact of gender-based debt equity in the past and present, and provides a positive and futuristic look at the treatment of women. In the past, females had a difficult time getting enrolled in college, having leadership roles, and accessing student loans. These factors were prominent because of the "glass ceiling" effect they faced whereby men dominated these roles. Furthermore, women were not socialized and/or expected to work outside the home. Most women were rearing their nuclear family with their husbands as the primary breadwinner. Hence, a college education was not seen as necessary. Starting in World War I women were needed to work both in and outside the home. More colleges were established and more females had easier and greater access to higher education. 


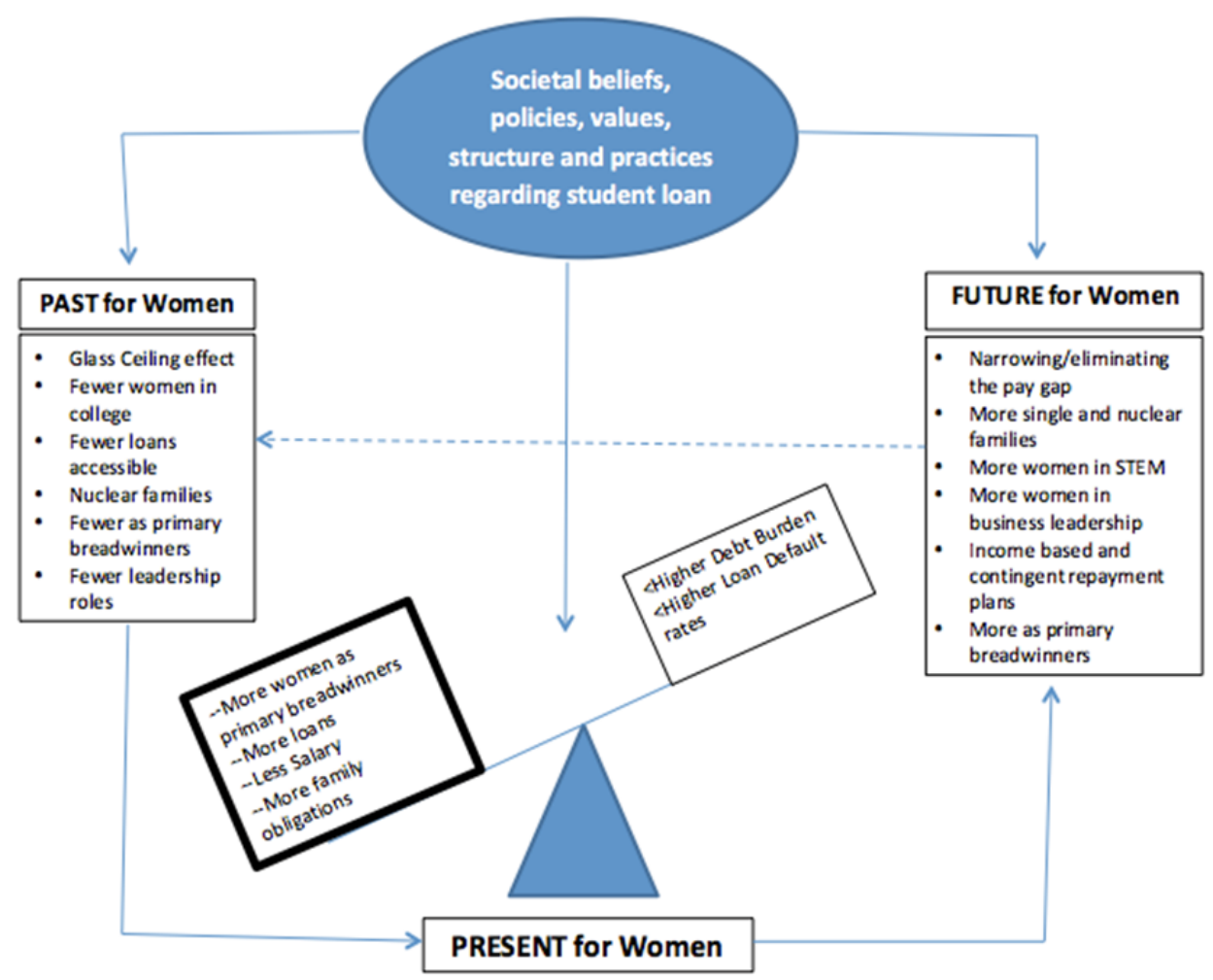

Figure 7. The impact of socialization on female graduates

Today, more women are head of households, leading to more family obligations. Women are represented in the workforce at a high rate yet they are generally compensated at a lower level when compared to their male counterparts. With more women enrolled in and graduating from institutions of higher education, these women have had greater access to student loans resulting in greater debts. This model suggests that women are burdened with more student loan debt than men. Hence, they are on the lower side of the "teeter totter" because of the higher debt burden leading to higher default rates on student loan repayment. This position of unequal burden is reflected 
in the darker and thicker lines surrounding the issues faced by many women repaying and accessing student loans. Together, societal beliefs, policies, values as well as the structure and practice of student loan acquisition impact gender equity in the past, present and future. This model suggests an optimistic future for women accessing student loans as more women graduate college assume breadwinner roles in families and leadership positions in the workplace. The "teeter totter" is not level for women as yet. With equitable compensation, more access to leadership roles and opportunities for career advancement there can be more balance or equality in how females are compensated. This equality will result in females having less student loan debt, lower default rates on loans and an equal or higher return on investment (ROI) for their pursuits in higher education.

\section{Recommendations}

The authors make the following suggestions to address pay inequality and help women ascend the career ladder as well as pursue entrepreneurial and leadership positions:

1. Pay equal salaries to both genders by providing incentives to employers to follow the laws that are in place for equal pay such as the Equal Pay Act of 1963.

2. Provide workshops to educate women and increase employee's awareness of the rules and regulations that address equal pay and fair practices.

3. Expand programs such as Pell grant to reduce the amount students have to borrow.

4. Provide educational training on income-based and incomecontingent loans repayment plans.

5. Provide information on programs that pay off student loans such as federal programs, military service, and teaching in high-need areas.

6. Motivate female students to pursue majors or careers that pay more such as those in STEM and business leadership fields.

7. Provide females with financial literacy regarding business and enterprising initiatives in leadership roles. 


\section{References}

American Association of University Women (AAUW) (2016a). For women, student loan debt is an even bigger crisis. Retrieved from http://www.aauw.org/2014/07/08/women-and-student-loan-debt/

American Association of University Women (AAUW) (2016b). Pay gap especially harmful for Black and Hispanic women struggling with student debt. Retrieved from http://www.aauw.org/2016/02/08/paygap-especially-harmful-for-black-and-hispanic-women-strugglingwith-student-debt/

Ayala, M. P., Lerner, M., \& Schwartz, D. (2010). Gender differences in entrepreneurship. Equality, diversity and inclusion: $A n$ International Journal, 29(2), 186-198. doi: http://dx.doi.org/10.1108/02610151011024493

Bowles, D. (2013). Toward an Integrated Theory of Social Stratification. American Journal of Economics \& Sociology, 72(1), 32-58. doi:10.1111/j.1536-7150.2012.00870.x

Corbett, C., Hill, C., \& American Association of University Women. (2012). Graduating to a Pay Gap: The Earnings of Women and Men One Year after College Graduation. American Association of University Women.

Crestwell, J. W. (2012). Educational Research: Planning, conducting, and evaluating quantitative and qualitative research $\left(4^{\text {th }}\right.$ ed.). Boston, MA: Pearson.

DiPrete, T., \& Buchman, C. (2006). Gender-specific trends in the value of education and the emerging gender gap in college completion. Demography, 43, 1-24.

Doherty, W., Willoughby, B., \& Wilde, J. (2016). Is the Gender Gap in College Enrollment Influenced by Non-marital Birth Rates and Father Absence?. Family Relations, 65(2), 263-274.

doi:10.1111/fare.12157

Ehrenberg, R. (2007). The economics of tuition and fees in American higher education. Cornell University ILR School Working Papers. Retrieved from http://digitalcommons.ilr.cornell.edu/cgi/viewcontent.cgi?article=106 $8 \&$ context $=$ workingpapers 
Ewert, S. L. (2012). Fewer Diplomas for Men: The Influence of College Experiences on the Gender Gap in College Graduation. The Journal of Higher Education, 6, 824.

Finnigan, A. (2015). Who are the breadwinning moms? Working Mother. Retrieved from http://www.workingmother.com/content/who-arebreadwinning-moms

Ginder, S., Kelly-Reid, J., \& Mann, F. (2015). Enrollment and Employees in Postsecondary Institutions, Fall 2014; and Financial Statistics and Academic Libraries, Fiscal Year 2014 (NCES 2016-005). U.S. Department of Education. Washington, DC: National Center for Education Statistics. Retrieved from http://nces.ed.gov/pubs2015/2015012.pdf

Gitman, L., \& Zutter, C. (2015). Principles of Managerial Finance (14ed). Boston: Prentice Hall.

Hill, C. (2016). Pay gap especially harmful for black and Hispanic women struggling with student debt. Retrieved from http://www.aauw.org/2016/02/08/pay-gap-especially-harmful-forblack-and-hispanic-women-struggling-with-student-debt/

Izadi, E. (2014, June). Are student loans a women's issue? The Atlantic.

Retrieved from

https://www.theatlantic.com/education/archive/2014/06/arestudent-loans-a-womens- issue/372218/

Kena, G., Hussar W., McFarland J., de Brey C., Musu-Gillette, L., Wang, X., Zhang, J., Rathbun, A., Wilkinson-Flicker, S., Diliberti M., Barmer, A., Bullock Mann, F., and Dunlop Velez, E. (2016). The Condition of Education 2016 (NCES 2016-144). U.S. Department of Education, National Center for Education Statistics. Washington, DC. Retrieved [date] from http://nces.ed.gov/pubsearch.

Kerbo, H. (2000). Social stratification and inequality: Class conflict in historical, comparative, and global perspective, 4th edition. New York: McGraw-Hill.

Kitroeff, N., \& Rodkin, J. (2015). The real payoff from an MBA is different for men and women. Bloomberg Businessweek (October 20, 2015). Retrieved from http://www.bloomberg.com/news/articles/2015-1020/the-real-cost-of-an-mba-is-different-for-men-and-women 
Long, B. T. (2010). Making college affordable improving aid policy. Issues in Science and Technology, XXVI, 4, Retrieved from http://issues.org/26-4/long-2/

Lucca, D.O., Nadauld, T., \& Shen, K. (2016). Credit supply and the rise in college tuition: Evidence from the expansion of federal student aid programs. Federal Reserve Bank of New York Staff Reports, No. 733. Retrieved from https://www.newyorkfed.org/media library/media/research/staff_reports/sr733.pdf

National Center for Education Statistics (NCES). (2016). Annual Earnings of Young Adults. Retrieved from http://nces.ed.gov/programs/coe/indicator_cba.asp

Parker, K. (2016). 6 facts about American fathers. Pew Research Center. Retrieved from http:/www.pewresearch.org/facttank/2016/06/16/fathers-day-facts/

Renehan, S. (2015). Rising Tuition in Higher Education: Should we be Concerned? Visions for the Liberal Arts, 1(1), Article 3. Retrieved from

http://scholar.oxy.edu/cgi/viewcontent.cgi?article=1001\&context=lib eralarts

ROI in Tertiary Education Report (2013). Retrieved from http:/www.conferenceboard.ca/hcp/details/education/tertiary.aspx Ruderman, D. (2016). More than half of all college graduates say recent grads will see a lower return on investment from their education, survey says. Greenwood Hall Inc. (February 2, 2016). Retrieved from http:/www.greenwoodhall.com/news/more-than-half-of-allcollege-graduates-say-recent-grads-will-see-a-lower-return-oninvestment-from-their-education-survey-says/\#.V5J1qTU4Tg8

Snyder, T. D., de Brey, C., \& Dillow, S. A. (2016). Digest of education statistics 2014. National Center for Education Statistics.

Snyder, Tekleselassie, A., Mallery, C., \& Choi, J. (2013). Unpacking the Gender Gap in Postsecondary Participation among African Americans and Caucasians Using Hierarchical Generalized Linear Modeling. Journal of Negro Education, 82(2), 139-156.

U.S. Department of Commerce, Census Bureau, Current Population Survey (CPS), Annual Social and Economic Supplement, 1996 through 2015. 
U.S. Department of Education, National Center for Education Statistics, 1999-2000, 2003-04, 2007- 08, and 2011-12 National Postsecondary Student Aid Study (NPSAS:2000, NPSAS:04, NPSAS:08, and NPSAS:12).

Willie, M. (2012). Taxing and tuition: a legislative solution to growing endowments and the rising costs of a college degree. Brigham Young University Law Review, 2012(5/6), 1665-1704.

Amany Saleh is professor at Arkansas State University, United States

QianQian $\mathbf{Y u}$ is pursuing a doctorate at Arkansas State University, United States

H. Steve Leslie is professor at Arkansas State University, United States

John Seydel is professor at Arkansas State University, United States

Contact Address: asaleh@astate.edu 